\title{
INSTITUTIONAL FORCES AND LIFE CYCLE STAGES OF WOMEN-LED SMES IN DEVELOPING ECONOMIES
}

\author{
Kumudinei Dissanayake \\ Department of Management \& Organization Studies, Faculty of Management \& Finance \\ University of Colombo, Sri Lanka. \\ kumudisa@mos.cmb.ac.lk
}

\begin{abstract}
Despite women 's enormous involvement in economic activities through Small and Mediumscale Enterprises (SMEs), their progress has been relativelyslow and the macro environmental influences impeding women-led SMEs have been numerous. These impediments vary at different life cycle stages of the women-led business. As informed by life cycle stage theories of organizations, the formation, establishment, continuation and growth stage of businesses each have their own characteristics and needs, and thus entail specific resource requirements to be fulfilled for proceed to the next stage and/or for ensuring survival. This knowledge builds reasonable certainty that the issues undergone by womenled SMEs may vary and be distinctive at diverse life cycle stages of their businesses. The institutional environment of a country can impose restrictions or facilitate growth of entrepreneurship and small businesses. Even though evidence on issues related to formation, establishment, continuity and growth of women-led SMEs are not rare in the existing literature, the impact of the institutional environment at various business life cycle stages have not been well investigated. Thus, the aim of this study is to examine the institutional forces that affect the businesses at diverse life cycle stages of women-led SMEs in developing economies. Drawing from the institutional theory, the present study examines the institutional environmental forces influencing women-led SMEs at different stages of the business life cycles. It develops several propositions, building relationships among three institutional forces and different life cycles stages passed by women-led SMEs. It examines the effects of regulatory, normative and cognitive dimensions of the institutional environment at developing economy contexts. Based on the previous research findings, it encapsulates how apex level environmental conditions of under-developed institutional environments affect the life course of grass-root level women-led SMEs. Concurrently, the findings shed light on which dimension(s) of the institutional environment are most significant at a distinctive stage of women-led SME.
\end{abstract}

Key Words: Institutional environment, Life cycle stages, SMEs, Women-led, Developing economies 


\section{INTRODUCTION}

Women's involvement in economic activities through Small and Medium-scale Enterprises (SMEs) has been enormous, especially in developing economies, despite their invisibility in reports either in numbers or in values. Empowerment of women through economic means has enabled developing nations to secure nutritional as well as educational needs of younger generations to a certain extent, and reduced poverty levels and gender inequalities in these societies (Shyamalie \& Saini, 2011).However, extant literature finds that women-led (or women-owned) SMEs are not operating up to their full potential, due to certain overwhelming issues encountered during their life course. Thus, slow-growth or stagnation, never growing or even premature death is visible in women-led SMEs all over the globe. Despite the availability of evidence that life cycle stages of women-led SMEs need considerable research attention, current literature still lacks records of sufficient investigation into this empiricism. As evidenced, the external environmental conditions of a business considerably affects the life course of a firm through birth and growth to death (Hannan\& Freeman, 1977). In a macro perspective, the institutional environmental forces, such as regulatory forces, knowledge base, and changing cultural and normative dimensions of the society (DiMaggio \& Powell, 1983) play a pivotal role in impeding or expediting the success of a business. The institutional perspective has been helpful in studying numerous effects on SMEs (e.g., Liu, Yang, \& Zang, 2012; Manolova, Eunni, \& Gyoshev, 2008; Roxas\&Coetzer, 2012; Zhu, Wittmann, \& Peng, 2012). Institutional environmental forces enacting on small and medium-scale enterprises (SMEs) and entrepreneurship in under-developed economies (Welter \& Smallbone, 2011) have been significant. They influence the start-up, growth and decline of a business.

As informed by life cycle stage theories of organizations, the formation, establishment, and growth stage of businesses each has its own characteristics and needs, and thus entail specific resource requirements to be fulfilledbefore proceeding to the next stage and/or for ensuring survival (e.g., Chandler, 1962; Quinn \& Cameron, 1983). This knowledge builds reasonable certainty that the issues undergone by women-led SMEs may vary and be distinctive at diverse life cycle stages of their businesses.

Wehere by identify a considerable void in the existing knowledge, which does not adequately explain the possible adverse effects those emanate from institutional environment at different stages of womenled SMEs. Accordingly, the aim of this study is to examine the institutional forces that affect the businesses at diverse life cycle stages of women-led SMEs in developing economies. Thus, drawing from the institutional theory, this study investigates the possible regulatory, normative, and cognitive forces those affecting the formation, establishment and growth stages of women-led SMEs. 
This study extends our understanding of institutional environmental level barriers vis-à-vis diverse life cycle stages of womenled SMEs. Specifically, it examines the effects of regulatory, normative and cognitive dimensions in the institutional environment at developing economy contexts. Based on the previous research findings on SMEs and entrepreneurship in general, and women-led SMEs in particular, current study encapsulates how apex level environmental conditions of underdeveloped institutional environments affect the life course of grass-root level women-led SMEs. Concurrently, the findings shed light on which dimension(s) of the institutional environment are most significant at a distinctive stage of women-led SMEs.

The structure of the paper is as follows. First, it presents an overview of institutional environment, with the focus oninstitutional environment in the context of business enterprises, and institutional environmental dimensions as used in this study. Then it reviews the characteristics of life cycle stages of SMEs as evidenced in theory and literature. Then, it discusses, in light of existing knowledge, the effects of institutional environment on life cycle stages of women-led SMEs at their formation, establishment and growth stages. In this attempt, it develops four propositions, which presents as an outcome of the study. Finally, it concludes by highlighting the implications drawn in the study and presenting directions for empirical research.

\section{REVIEW OF LITERATURE}

\subsection{The Institutional Environment in the Context of Business Enterprises}

Adopting a macro level viewpoint towards society, the institutional perspective (DiMaggio \& Powell, 1983; Scott, 1995; Zucker, 1983) has created theoretical grounds to examine the causes that impede or expedite the operations, growth, and success of SMEs. As explained by Manolova, Eunni, and Gyoshev (2008), the institutional environment defines, creates, and limits entrepreneurial opportunities, thus creating or destroying entrepreneurship in a country (p. 205).Moreover, institutional environmental effects on business are strong in developing economies due to their persisting under-developed nature. Seemingly, the informal, small and medium business sectors are subject to seen or unseen influences of institutional environment. Accordingly, the institutional perspective has been helpful in studying numerous effects on SMEs, including family business, firm performance, innovation in SMEs etc. (e.g., Liu, Yang, \& Zang, 2012; Manolova, et al., 2008; Roxas\&Coetzer, 2012; Zhu, Wittmann, \& Peng, 2012). Previous studies witness its use in research into entrepreneurship (Manolova, et al., 2008; Gupta, Yayla, Sikdar, \& Cha, 2012; Roxas\&Coetzer, 2012; Tang \& Tang, 2012), entrepreneurial behavior (Welter \&Smallbone, 2011), and small firms (Urban, 2013). As evidenced by the above sources of literature, most of the previous attempts at using institutional framework to understand 
SME and entrepreneurial activities have ignored the women-led SMEs, and its impact on life cycle stages, especially in developing economies.

\subsection{Dimensions of Institutional Environment}

The three dimensions: regulatory, cognitive, and normative (Scott, 1995) have been used to explain the influence of institutional environment on business enterprises. The regulatory dimension represents the formal, structured, codified, and explicitly held guides for business decisions and actions, which are enforced through enactment of regulations, laws, Acts etc. The cognitive dimension exhibits the knowledge base accumulated through common practices and held explicitly or implicitly in the business community. The normative dimension composites informal, implicitly held or internalized system of values, norms, beliefs, traditions etc. belonging to a particular society (Arasti, Pasvishe, \&Motavaseli, 2012; Busenitz, Gomez, \& Spencer, 2000; Roxas\&Coetzer, 2012; Welter \& Smallbone, 2011). Thus, business enterprises, irrespective of their scale, operate in a fusion of regulatory, cognitive, and normative environments. Figure 2.1 below depicts the conceptualization made to achieve the objectives in the present study.

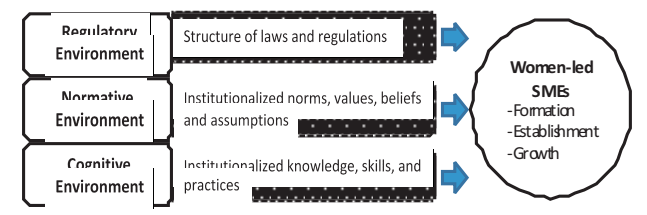

Journal of Business Studies
Figure 2.1: The Impact of Institutional Environment on Women-led SMEs

Source: Developed by the researcher

\subsection{Characteristics of life cycle stages of SMEs as evidenced in theory and literature}

\section{Formation (Idea Generation)}

Previous research has accorded attention on the business start-up or venture creation process of SMEs, and their different stages. According to Schapero and Sokol (1982), life path changes of people may lead to perceptions of desirability of starting a business, and then it can lead to perceptions of feasibility, which ultimately enables an entering into firm formation. At the initial stage, a significant influence on forming a business draws from the stock of possibilities, which are later, transited into conceptions (Reynolds, Carter, Gartner, \& Greene, 2004). Accordingly, nascent entrepreneurs (who seriously intent to start a business and whose efforts may or may not culminate in the birth of a new firm) (Katre \& Salipante, 2012; Reynolds, 2009) or potential entrepreneurs (who really become entrepreneurs after all) (Arenius \& Ehrstedt, 2008, p.134) may be born in such a process.

Previous studies on entrepreneurial venture creation and small business formation have discussed the initial stage of this process with the use of different conceptions. For instance; opportunity discovery (Shane, 2000), entrepreneurial event formation (Schapero \& Sokol, 1982), venture ideas during the start-up (Davidsson, Hunter, \& Klofsten, 2006), process of new venture 43 Issue II - 2016 
creation (Davidsson\&Gordan, 2012), nascent and new firms creation (Zinger, Lebrasseur, Robichaud, \&Riverin, 2007) focus on the initial stage of SMEstart-up, which the present study identifies as 'idea generation' or 'formation' stage of an SME.

\section{Establishment (Creation)}

The establishment stage of an SME demands confirmation of the decision of venture creation by making it a reality and ensuring survival after creation. Thus, it calls for business registration and allied functions, after which a firm comes to existence. The entrepreneurial process, followed by the gestation process, lead to a transition into firm birth (Reynolds, Carter, Gartner, \& Greene, 2004). The firms that evolve in such a manner may be established and may continue to survive under diverse conditions, which inevitably affect their smooth functioning. As evidenced through the existing literature, the entrepreneurial start-up process (Arenius \& Ehrstedt, 2008), new venture financing (Alsos, Isaksen \& Ljunggren, 2006), and new firm formation (Davidsson, Lindmark \& Olofsson, 1995) imply the 'establishment stage' of SMEs.

\section{Growth, Stagnation or Decline (Continuation or Withdrawal)}

Growth stage of the SMEs has been the topic of investigation for several studies. Growth of the small firm (Davidsson, 1991; Penrose, 1959), growth willingness (Davidsson, 1989), high-growth firm (Delmer, Davidsson \& Gartner, 2003), role of knowledge acquisition on entrepreneurial Journal of Business Studies growth (Naldi \& Davidsson, 2014), and small firm performance (Begley \& Boyd, 1987) are some of the research areas explored.

Growth aspects of women-led small businesses are not rare in the existing body of knowledge. Some recent investigations can be found in Costin (2012), Dalborg, von Friedrichs and Wincent (2012), Mitchelmore and Rowley (2013a), Mitchelmore\& Rowley (2013b), and Mitchelmore, and Rowley and Shiu (2014).However, all SMEs that establish their operations at the second stage are not move smoothly to the growth stage, but instead may encounter difficulties and thus continue in the same status without any further growth. Alternatively, some SMEs may even decline and reache close-up (death) even after passing the establishment stage of their life cycles. Figure 2.2 below precisely presents the life cycle stages of SMEs.

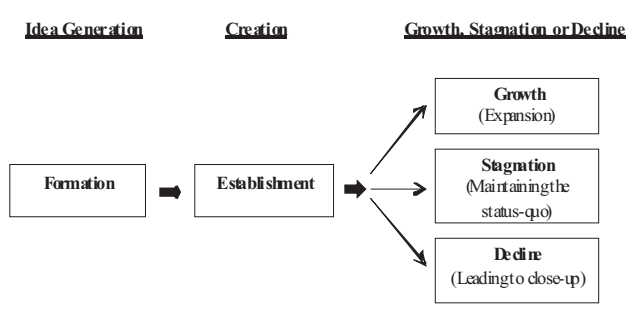

Figure 2.2 Life cycle Stages of SMEs

Source: Developed by the researcher

Life cycle stages of women-led SMEs: Any difference?

With the acknowledgment of the dearth of theorization and literature on investigation 4 Issue II - 2016 
of life cycle stages of women-led SMEs, the present study identifies a similar absence of conceptualizations of any differences between the life cycle stages of men-led and women-led SMEs. Among the extant literature that focus on barriers, challenges, and issues encountered by women in business, it has been difficult to find a complexmodel of their life cycle stages. Accordingly, wepoint out that the simple three-stage model set forth above would sufficiently cover the life span of a womenled SME.

\subsection{The case of developing economies}

Developing economies undergo undeveloped institutional environments (Welter \& Smallbone, 2011) which do not support or sometimes even hinder the enterprise development. They believe in bureaucratic organizations and systems (Daft, 2013) for better performance. Seemingly, bureaucratic organizations maintaining rigid rules and regulations, financial regulations with restricted investments, and the burden of taxes irrespective of the scale of business are common in less-developed and developing nations. In addition to these, unequal distribution of resources and opportunities in the society, and the lack of mechanisms established for protecting disadvantaged (or minority) groups entering into business are commonly visible in such nations, especially when compared to the relative lack of these impediments in developed nations.
World Bank (2011) implies that formal and informal institutions themselves in developing countries help to maintain gender gaps in development. The World Bank accentuates the need of influence and evolution of formal institutions (such as regulatory frameworks, laws, and service delivery mechanisms of the state) in order to bridge this gap. It further mentions the need for shaping informal institutions to serve this purpose.

Barriers on women's access to institutionalized knowledge and practices, together with norm-based occupational segregation(Kyrö, 2009) in the business environments in developing economy contexts, have created 'glass fences' which restrict women's stepping into certain mendominating or men-successful business segments. Thus, the developing economy context suggests a more vulnerable institutional environment for women-led SMEs.

\section{EFFECTOF \\ INSTITUTIONAL ENVIRONMENT ON \\ LIFECYCLE STAGES OF WOMEN-LED SMES}

\subsection{Institutional environment: How it affects lifecycle stages of women-led SMEsin developing economies}

The above review demonstrates that lifecycle of SMEs passes through several stages which demand diverse types of 
competencies and resources from individual and institutional environments.

\section{Formation stage of women-led SMEs}

Even though the initial entrepreneurial decision is an individual one, the individual desire or attitude towards business formation is significantly influenced by environmental factors. Schapero and Sokol (1982) posit that entrepreneurial event formation is led by individual perceptions which are created and shaped by the surrounding environment. Thus, the perception of desirability, which is initially shaped by the immediate external environment, may lead to a perception of feasibility which is created and supported by the supportive environment (Schapero \& Sokol, 1982) such as financial, regulatory, legislative, and other. General environmental conditions prevailing in the economy is one category of the factors that influence the initial entrepreneurial decision (Cooper, 1981). Thus, existing taxation policy, enterprise registration procedure, capital investment opportunities supported by the government, business start-up loan schemes, and access available to support services become critical determinants in venture creation. Focusing on business startups, Rouse and Jayawarna (2011) point out that labor market restrictions act as disadvantageous to women's initial investment in business.

The prevailing socio-cultural environment of a country influences the individual attitudes towards creating a small business. Journal of Business Studies
The norms of behavior accepted by the society, traditional family relationships and their influences, availability of networks and advices in society, and the national culture of the country as a whole influence the attitudes of women entrepreneurs at venture creation (Birley, 1989).Social support for women entrepreneurs during the venture creation plays a pivotal role (Fielden \& Hunt, 2011). Kantor (2002) emphasizes that women in South Asia are not in a position to make strong decisions in their businesses due to family or gender relations, which they do not want to damage. Dependency on males for important decisions and fear of social isolation due to the breaking of social norms have been major obstacles to the creation of women's entrepreneurship (Kantor, 2002, p. 139). Gaining ownership of assets and getting access to capital or investment for business start-up is another major issue encountered by women in South Asia. Further, sexual division of labor and restrictions on physical movements are seen as socially created impediments for women's entering into SMEs in this region (Kantor, 2002).

An individual's perception of selfcompetence plays a vital role at the decision making stage of initial venture creation. Perception of skills and knowledge, level of education (Cooper, 1981), experiences earned from previous career and occupational background (Schapero \& Sokol, 1982) are important factors influencing the entrepreneurial decision of an individual at the outset. Further, a strong Issue II - 2016 
belief that one has the capability to start a business or even fear of failure (World Bank, 2014) is influential during business start-up. Lack of institutionalized knowledge in women vis-à-vis business can be a consequence of this condition. On the other hand, the extent to which the society perceives a woman's competenceat initiating a business, and social belief on her ability to align with the socially accepted business practices also influence the entrepreneurial decision of a woman. Further, a relative lack of investment in female education, when compared to that in male education in South Asia has become a factor leading to less recognition, lack of qualifications, less training, and less experience at work, which then leads society to undermine the capability and risk-taking behavior of women at business start-up. Thus, at this juncture, we arrive at the following proposition:

Proposition 1:Institutional environmental forces(regulatory, cognitive and normative) adverselyaffect the formation stage of women-led SMEs in developing economies.

\section{Establishment stage of women-led SMEs}

If women succeed in the formation stage of their business, it will be less likely to beaffected by the normative and cognitive pressures of a society at the establishment stage. However, thereby, the strongest hurdle would be the formal establishment of the enterprise. Moving from the formation stage (idea generation) to the establishment stage (creation) of an SME inevitably requires the support from the regulatory environment. The establishment stage of a businessis unavoidably affected by certain regulatory requirements, which comes to the force by the existing rules of the state. A regulatory environment, on the one hand assures the order ofa society, and on the other hand creates barriers to business on several occasions. International Finance Corporation (IFC) reports that institutional and regulatory issues are major contributors to the slow growth rate of women's enterprises in developing countries (2011).Comparing the impact of institutions on men's and women's decisions to establish new business start-ups, Estrin and Mickiewicz (2011) found that women are less likely to undertake entrepreneurial activity in countries where the state sector is larger. Thereby, rule of law, rule ofproperty rights, and the cluster of regulations and policies determined by the government were considered under the context of institutions. Capital investment may be the most critical resource for establishing an SME in a developing economy. Obstacles in obtaining access to initial investment have created significant issues in women-led SMEs. Women entrepreneurs have lower access to finance than do male entrepreneurs (IFC, 2011) throughout the region. Regulatory requirements imposed by the central governments as well as local government authorities have been partly responsible for this macro environmental situation. Some of the major points that repeatedly highlighted in literature accumulates around women entrepreneurs' difficulty in obtaining loans 
from formal sources due to the requirement of collaterals, highly formalized procedures, long and complicated documentation etc. Accordingly, we propose the following:

Proposition 2:Structure of laws, rules and regulations (regulatory dimension of the institutional environment) in developing economies hinders the smooth movement of women-led SMEs from the formation stage (idea generation) to the establishment stage (creation).

\section{Growth, continuation or withdrawal stage of women-led SMEs}

Moving smoothly towards the growth stage of a business requires more resources (Quinn \& Cameron, 1983), i.e., financial, human, physical capital, information, and marke tresources. Accessibility to resources in this stage by men and women has been reportedly different. For instance, the ways that men and women entrepreneurs access informal finance resources are significantly different (Jayawarna et al., 2012). Lack of business information, business opportunities, and network connections (IFC, 2011) are at present hindering the growth of women-led SMEs. The enterprises managed by femalesin most of the developing economies have demonstrated less growth when compared to the enterprises managed by their male counterparts. Coad and Tamvada (2012), in a study of small business structure in India, reported that small firms managed by women have a lower expected growth rate.
This fact has been rationalized in the existing literature through the following arguments. Women-led businesses frequently suffer from lack of business information for formulating their growth strategies. Further, women's lack of access to important advice, business networks, and support systems in order to develop their businesses have enforced barriers for growth (Sing, Reynolds \& Mohammad, 2001). Thus, we propose:

Proposition 3:Restricted access to institutionalized knowledge in the SME sector (cognitive dimension of the institutional environment) hinders the smooth movement from the establishment stage to growth stage and expedites the decline of women-led SMEs in developing economies.

For a women-led SME to become an established enterprise, it may have to fulfill the regulatory and cognitive requirements in the business environment. Thus, if it becomes established, then the intensity of the effects of regulatory and cognitive forces in the institutional environment will be minimal at the next stage of its life. However, for the usual business to be transformed into a growing business, there would need acceptance and favorable attitudes from the larger society as well. Therefore, society's role in forming favorable or unfavorable attitudes towards women's business has been vital. 
The general society views women's involvement in business differently to that of men's (Birley, 1989). As Birley (1989) identifies, the role of national culture, acceptable norms of behavior of women entrepreneurs and traditional family relationships are vital in forming the social attitudes towards women-led SMEs. In particular, Asian cultureis characterized with unique traditional systems and ethics. In these traditional family systems and extended families with elder decision making, patriarchal society and the resultant male-centered and male-dominated income generation, the preference for male business successors (Wees \& Romijn, 1995) suggest that society makes it difficult for women to reach the pinnacle of business success. Wees and Romijn further reveals that women's seriousness and credibility is still doubted in Asian society. Gender-based occupational segregation in Asian society too predetermines women's position in society (Kyrö, 2009), and consequently the viability of women-led SMEs. Thus, women-led SMEs in developing economies experience low esteem which hinders their gradual development.

Proposition 4: Institutionalized norms, $\mathrm{v}$ a $1 \mathrm{u}$ e s, b e $1 \mathrm{i}$ e $\mathrm{fs}, \quad \mathrm{a} \mathrm{nd}$ assumptions(normative dimension of the institutional environment)in developing economies hinder the growth of established women-led SMEs.

\section{CONCLUSION AND IMPLICATIONS}

\subsection{Conclusion}

This study iterates three-fold discernments in developing its thesis. First, it contends that the institutional differences recognized at contextual levels (developing economy in the present study) provide a rich source of evidence for decision-making bodies in such contexts. Second, it emphasizes that scholarly attention focused on institutional environment and its impact on SMEs is inadequate if policy makers are not informed sufficiently the particular stage of business life cycles that they need to interfere. Third, it assures that identification of institutional environment's impact on SMEs observed through the lens of gender will widen opportunities for designing specific policies at grass-root level, especially for the minority group. Thus, it recapitulates the need to identify the impact of the institutional environment at different life cycle stages of women-led SMEs.

This study did not attempt to differentiate and identify any differences of the institutional forces that affect men- and women-led SMEs. Instead, more importantly, attention was accorded to identify how institutional forces would impede or expedite smooth progression of women-led SMEs throughout their life course. As suggested by the existing evidence, we conclude that an average treatment meted to all the enterprises in the same field would not yield better results 
unless their existing life cycle stages are not paid considerable attention, due to the fact that certain crucial issues, which need special attention at certain life cycle stages, would be unseen, neglected or undermined. Extending the above view, we further deduce that each life cycle stage of womenled SMEs may face adistinctive institutional barrier, which claim special attention and a unique treatment. Thus, closer monitoring and customer-made supportive mechanisms would be of immensely beneficial at diverse stages in their life courses. Strengthening women-led SMEs by removing or lessening institutional barriers at these life cycle stages should, undoubtedly, be one important step in national-level SME policies.

\subsection{Implications}

The present study confirms the importance of looking into institutional environmental forces vis-à-vis life cycle stages of womenled SMEs I then developing economy context. Close monitoring of the timely progression and related issues of SMEs may help governing bodies take necessary steps for assuring their smooth functioning and development.

This study presents the view that the formation stage of women-led SMEs is affected by regulatory, normative and cognitive forces of the institutional environment. This reminds us that business formation is the most crucial stage, which is subjected to a vast range of influences flowing from macro level environment for
Thus, SME development agencies may need to capitalize more strength and resources at this stage.

The establishment stage of women-led SMEs require more flexibility and support from regulatory bodies. However, it is unrealistic to expect that existing rules and regulations can be changed or revised for facilitating women-led business with immediate effect. Instead, it may be a proactive step to establish women-friendly supportive services for help at this stage.

In stepping from the establishment to the growth stage, women SMEs may need more rich knowledge on business practices, techniques, and strategies. Further, in order to maintain a steady growth in already established SMEs, women may need support from society at large. However, the attitude that the society holds towards women's SMEs would be influenced partly by women them-selves. Thus, entrepreneurial education for the established SME owners would be more beneficial at this stage.

\subsection{Future research directions}

Examining the stages of life cycles of enterprises will not be an easy task. However, longitudinal studies and historical analysis of enterprises (ex., Chandler, 1962) have been successful in this attempt. Life cycle studies of enterprises reveal numerous issues and problems, which cannot be understood and addressed through any other investigations. 
Three possible studies could be suggested at this point. First, a comprehensive empirical investigation of the life cycle stages of women-led SMEs would help to fill the void in existing knowledge. This may be more meaningful if the investigations are contextspecific, and thus reveal the life course of enterprises in developed and developing economies separately.

An empirical investigation of the proposed relationships would enrich our knowledge on life cyclestages of women-led SMEs as well as the institutional environment and its real impact on SMEs. Such an investigation would bring new insights if a comparison of both men and women-led SMEs were incorporated in the study as the behavior of institutional forces could reveal interestingly different impacts in the event that gender is considered.

Further, an empirical examination of lifecycle stages of women-led SMEs would unveil more areas for future research.

\section{REFERENCES}

Acs, Z. J., Bardasi, E., Estrin, S., \&Svejnar, J. (2011). Introduction to special issue of small business economics on female entrepreneurship in developed and developing economies, Small Business Economics, 37, 393-396.

Alsos, G.A., Isaksen, E.J. \&Ljunggren, E. (2006).New Venture Financingand SubsequentBusiness Growth inMen- and Women-LedBusinesses, Entrepreneurship Theory and Practice,30(5), 667-686.

Arasti, Z., Pasvishe, F. A., \& and Motavaseli, M. (2012). Normative institutional factors affecting entrepreneurial intention in Iranian information technology sector. Journal of Management and Strategy, 3(2), 1624.

Arenius, P., \&Ehrstedt, S. (2008). Variation in the level of activity across the stages of the entrepreneurial startup processevidence from 35 countries, Estudios de Economía, 35(2), 133-152.

Bardasi, E., Sabarwal, S., Terrell, K. (2011). How do female entrepreneurs perform? Evidence from three developing regions, Small Business Economics, 37, 417-441.

Birley, S. (1989). Female entrepreneurs: Are they really any different? Journal of Small Business Management, 27(1), 32-37.

Busenitz, L., Gomez, C., \& Spencer, J. (2000). Country institutional profiles: Unlocking entrepreneurial phenomena. Academy of Management Journal, 43(5), 994-1003.

Chandler, A. D. (1962). Strategy and structure. Chapters in the history of the 
Industrial enterprises. Cambridge, Mass.: MIT Press.

Cooper,A.C. (1981). Strategic management: New venture and small business, Long Range Planning, 14(5), 39-45.

Costin, Y. (2012). In pursuit of growth: an insight into the experience of female entrepreneurs, International Journal of Gender and Entrepreneurship, 4(2), 108-127.

Dalborg, C., von Friedrichs, Y.\&Wincent, J. (2012). Beyond the numbers: qualitative growth in women's businesses, International Journal of Gender and Entrepreneurship, 4(3), 289-315.

Daft, R. L. (2012). Organization theory and design, USA: South-Western Cengage Learning.

Davidsson. P. (1989). Entrepreneurship-and after? A study ofgrowth willingness in small firms.Journal of Business Venturing, 4, 211-226.

Davidsson, P., Hunter, E. \&Klofsten, M. (2006).Institutional forcesthe invisible hand that shapes venture ideas? International Small Business Journal,24(2), 115-131.

Davidsson, P., Lindmark, L. \&Olofsson, C. (1995).Small Firms, Business
Dynamics and Differential Development of Economic WellBeing, Small Business Economics,7, 301-315.

DiMaggio, P. J., and W. W. Powell (1983). The iron cage revisited: Institutionalisomorphism and collective rationality in organizational fields, American Sociological Review, 48, 147160.

Estrin, S., \& Mickiewicz, T. (2011). Institutions and female entrepreneurship, Small Business Economics, 37, 397-415.

Fielden, S. L. \& Hunt, C. M. (August, 2011). Online coaching: An alternative source of social support for female entrepreneurs during venture creation, International Small Business Journal, 29(4), 345-359.

Gupta, V. K., Yayla, A.A., Sikdar, A., \& Cha, M. (2011). Institutional environment for entrepreneurship: evidence from the developmental states of South Korea and united Arab Emirates, Journal of Developmental Entrepreneurship, 17(3), 1250013 (21 pages)DOI: $10.1142 / \mathrm{S} 10849467$ 12500136

Hannan, M.T. \& Freeman, J. (1977). The population ecology of organizations. The American Journal of Sociology, 82(5), 929-964. 
International Finance Corporation (IFC) (2011). Strengthening access to finance for women-owned SMEs in developing countries. (Author). Retrieved on 20 June 2014 through:http://www.ifc.org/wps/wcm/ connect/a4774a004a3f66539f0f9f896 9adcc27/G20_Women_Report.pdf?M OD=AJPERES (accessed 20 June 2014).

Jayawarna, D., Rouse, J. \&Kitching, J. (February 2013). Entrepreneur motivations and life course, International Small Business Journal,31(1),34-56.

Jayawarna, D., Woodhams, C., \& Jones, O. (October 2012). Gender and alternative start-up business funding, Competition and Change, 16(4), 303322.

Kantor, P. (2002). Gender, microenterprise success and cultural context: The case of South Asia, Entrepreneurship: Theory and Practice, 131-143.

Katre, A. \&Salipante, P. (2012). Start-up social ventures: blending fine-grained behaviors from two institutions for entrepreneurial success, Entrepreneurship Theory and Practice, 967-994. DOI: 10.1111/j.1540-6520.2012.00536.x entrepreneurs to start businesses in all countries? Journal of Small Business Management, 42-51.

Kyrö, P. (2009). Gender lenses identify different waves and ways of understanding wo me n entrepreneurship, Journal of Enterprising Culture, 17(4), 393418.

Liu, W., Yang, H. \&Zang, G. (2012). Does family business excel in firm performance? An institution-based view. Asia Pacific Journal of Management, 29, 965-987.

Manolova, T.S., Eunni, R.V., \&Gyoshev, B.S. (2008). Institutional environments for entrepreneurship: Evidence from emerging economies in Eastern Europe. Entrepreneurship Theory and Practice, 32(1), 203-218.

Mitchelmore, S.,\& Rowley, J. (2013). Entrepreneurial competencies of women entrepreneurs pursuing business growth, Journal of Small Business and Enterprise Development, 20(1), 125-142.

Mitchelmore, S., Rowley, J.,\&Shiu, E. (2014). Competencies associated with growth of women-led SMEs, Journal of Small Business and Enterprise Development, 21(4), 588-601.

Kolvereid, L., Shane, S., \&Westhead, P. Penrose, E., (1959). The Theory of the (1993). Is it equally difficult for female 
Growth of the Firm. Oxford Univ. Press, Oxford.

Quinn, R. \& Cameron, K. (1983). Organizational life cycles and shifting criteria of effectiveness: some preliminary evidence, Management Science, 29, 33-51.

Reynolds, P.D. (2009). Screening item effects in estimating the prevalenceof nascent entrepreneurs, Small Business Economics, 33, 151-163.

Reynolds, P.D., Carter, N.M., Gartner, W.B., $\&$ Greene, P.G. (2004). The Prevalence of Nascent Entrepreneurs in the United States: Evidence from the Panel Study of entrepreneurial Dynamics, Small Business Economics, 23: 263284.

Rouse, J. \&Jayawarna, D. (2011). Structures of exclusion from enterprise finance, Environment and Planning $C$ : Government and Policy, 29,659 676.

Roxas, B. \&Coetzer, A. (2012). Institutional environment, managerial attitudes and environmental sustainability orientation of small firms. Journal of Business Ethics, 111, 461-476.

Schapero, A. \&Sokol, L. (1982). The social dimensions of entrepreneurship. In K. Vesper, D. Sexton, and C.A. Kent (eds.), Encyclopedia of entrepreneurship, Englewood Cliffs, NJ: PrenticeHall.
Scott, W. R. (1995). Institutions and organizations. Thousand Oaks: Sage.

Sengupta, A., Datta, S.K., \&Mondal, S. (2013). Women's entrepreneurial abilities: A study in the Indian informal service sector, The Journal of Entrepreneurship, 22(2), 223243.

Shane, S. (2000). Prior knowledge and the discovery of entrepreneurial opportunities, Organization Science, 11(4), 448-469.

Shyamalie, H.W., \& Saini, A.S. (2011). Socio-economic status and livelihood security of women in the hills of India and Sri Lanka, New Delhi: Readworthy Publications (P) Ltd.

Singh, S. P., Reynolds, R.G., Muhammad, S. (2001). A Gender-based performance analysis of micro and small enterprises in Java, Indonesia, Journal of Small Business Management, 39(2), 174182.

Tang, Z. \& Tang, J. (2012). Entrepreneurial orientation and SME performance in China's changing environment: The moderating effects of strategies, Asia Pacific Journal of Management, 29, 409-431.

UNWOMEN (official web page). Retrieved on 24th May 2014 through http://www.unwomen.org/en/wherewe-are/asia-and-the-pacific 
Urban, B. (2013). Social entrepreneurship in an emerging economy: A focus on the institutional environment and social entrepreneurial self-efficacy, Managing Global Transitions, 11(1), 3-25.

Wees, C.V.D. \&Romijn, H. (1995). Entrepreneurship and small- and microenterprise development for women: A problematique in search of answers, a policy in search of programs. In L. Dignard and J. Havet (eds.), Women in micro- and smallscale enterprise development, London: IT Publications, 41-82.

Welter, F.\&Smallbone, D. (2011). Institutional perspectives on entrepreneurial behavior in challenging environments, Journal of Small Business Management, 49(1), 107125.

Williams, D. A., \&K'nIfe, K. A. K. (2012). Correlates of gender and credit behavior in small firms: Evidence from a small, developing economy, Entrepreneurial Executive, 17, 69 85.

World Bank (2011). Gender equality and development, World Bank Report 2012. World Bank. (Author).
2014 through http://web.worldbank. org/WBSITE/EXTERNAL/ TOPICS/EXTGENDER/0, content MDK: $23392638 \sim$ page PK : 210058 piPK:210062 theSitePK:33 $6868,00 . \mathrm{html}$

Zhu, Y., Wittmann, X. \&Peng, M.K. (2012). Institution-based barriers to innovation in SMEs in China. Asia Pacific Journal of Management, 29, 1131-1142.

Zinger, J.T., Lebrasseur, R., Robichaud, Y. \&Riverin, N. (2007). Stages of small enterprise development: A comparison of Canadian female and male entrepreneurs, Journal of Enterprising Culture, 15(2), 107-131.

Zucker, P. S. (1983). Institutional sources ofchange in the formal structure of organizations: The diffusion of civil service reform, 1880-1935. Administrative Science Quarterly, 2239.

World Bank (2014). Gender and Development, Retrieved on $27^{\text {th }}$ June 